\title{
KIAT PENJUAL MAKANAN TRADISIONAL DALAM MENEMBUS PASAR
}

\section{THE TIPS OF THE TRADITIONAL FOODS SELLER TO EMERGE THE MARKETS}

\author{
Ria Intani T. \\ Balai Pelestarian Nilai Budaya Bandung \\ Jl. Cinambo No. 136 Ujungberung-Bandung \\ e-mail: ria_intani@yahoo.com
}

\begin{abstract}
Abstrak
Memasuki zaman globalisasi dapat dikatakan segalanya serba modern. Tidak heran kalau kemudian orang mulai meninggalkan hal-hal yang berbau tradisional. Fenomena yang cukup menonjol terjadi pada makanan. Makanan dengan nama-nama asing booming hingga menomorduakan makanan tradisional. Itu dulu. Belakangan, beberapa makanan tradisional kembali bangkit dan bahkan booming di kalangan anak muda khususnya. Makanan yang dimaksud adalah seblak. Penelitian tentang fenomena ini sangat penting untuk mengetahui kiat-kiat apa yang dilakukan pegiat makanan tradisional hingga makanan yang diproduksinya dapat diterima kembali di era sekarang ini. Dari kiat-kiat tersebut bukan tidak mungkin dapat dijadikan model untuk membangkitkan kembali jenis makanan tradisional lainnya dari keterpurukannya. Penelitian ini bersifat deskriptif dengan pendekatan kualitatif. Hasil penelitian menunjukkan bahwa makanan tradisional, dalam hal ini seblak, dapat diterima kembali kehadirannya di tengah-tengah makanan modern. Keberterimaan tersebut tidak lain karena pelaku usaha mau terus belajar, membuat inovasi, dan melihat budaya sebagai sesuatu yang dinamis. Hal ini menunjukkan bahwa kebudayaan merupakan sebuah aktivitas, merupakan sebuah produk dan ide, sekaligus proses belajar.
\end{abstract}

Kata kunci: kebangkitan, makanan tradisional, seblak.

\begin{abstract}
Entering the era of globalization can be said of everything modern department. No wonder then people started leaving things that related to the traditional thing. The phenomenon is quite prevalent in the food. Foods with foreign names booming until subordinated the traditional food. That was then. Later, some of the traditional foods arise and even boom among young people in particular. The food in question is seblak. Research on this phenomenon is very important to know what tips do traditional food producer to produced acceptable food in this era. From the tips it is not possible that the models could be used to revive other types of traditional food. This is a descriptive study with a qualitative approach. The results showed that the traditional food, in this case seblak, be welcomed back its presence in the midst of modern food. Acceptance is not because businesses want to continue to learn, to innovate, and to see culture as something dynamic. This suggests that culture is an activity, is a product and ideas, as well as the process of learning.
\end{abstract}

Keywords: arise, traditional food, seblak. 


\section{A. PENDAHULUAN}

Pangan atau lebih umum dikatakan makanan merupakan salah satu kebutuhan pokok manusia dalam melangsungkan kehidupannya. Ada beberapa definisi tentang makanan. Menurut Slamet Prawirohartono dalam Ria Andayani S. (2006: 120), yang dimaksud dengan makanan adalah bahan-bahan yang diperlukan tubuh supaya tetap hidup. Definisi lain adalah yang diungkapkan oleh Nur A. Z. dkk. dalam Nina Merlina (2006: 95-96) bahwa yang dimaksudkan dengan makanan adalah segala sesuatu yang dapat dimakan dan diminum, yang berkhasiat bagi tubuh, dapat berupa makanan pokok, lauk-pauk, sayuran, penganan, dan berbagai jenis minuman. Diutarakan oleh Satjadibrata (Kusumah, Siti Dloyana dan H. Ahmad Yunus, 1986: 28) bahwa bagi orang Sunda, yang dimaksud dengan makanan adalah kadaharan yakni suatu benda yang dapat dimakan.

Tentang fungsi makanan, oleh Oto Soemarwoto dalam Ria Andayani S. (2006: 120), dikatakan bahwa makanan atau pangan berfungsi sebagai penyusun tubuh, sumber energi, dan pengatur metabolisme. Karena itu, di samping kuantitas pangan, mutu pun penting. Mutu ditentukan oleh susunan berbagai unsur dalam bahan makanan, seperti karbohidrat, lemak, protein, mineral, dan vitamin. Selain itu, Oto juga mengatakan bahwa kebudayaan juga memberikan nilai sosial pada makanan. Ada makanan yang dianggap memiliki nilai sosial tinggi dan adapula makanan yang dianggap memiliki nilai sosial yang rendah (2006: 187).

Melengkapi tentang fungsi makanan seperti yang diutarakan oleh Oto, Siti Dloyana Kusumah dan H. Ahmad Yunus mengatakan bahwa tujuan dari memakan makanan adalah untuk menjaga supaya kondisi tubuh tetap segar bugar, memiliki tenaga yang kuat, dan berguna untuk menunaikan perjuangan hidup. Oleh karena itu pula setiap harinya manusia menurut kodratnya harus makan demi kesehatan tubuhnya dan demi kelangsungan hidupnya.

Dilihat dari segi jenisnya, makanan terbagi atas makanan berat dan makanan ringan. Dalam Kamus Besar Bahasa Indonesia (KBBI), dituliskan bahwa makanan ringan sama dengan kudapan atau makanan kecil (2013: 862). Dapat diartikan bahwa makanan kecil bukanlah makanan yang dapat sekaligus mengenyangkan, melainkan sekadar makanan selingan di antara waktu-waktu makan. Apakah itu makanan berat maupun ringan, keduanya diciptakan sesuai dengan kondisi zamannya.

Makanan juga digolongkan atas makanan jajanan dan makanan rumah. Makanan rumah merupakan makanan yang biasa tersedia di rumah. Adapun makanan jajanan diperoleh dengan berjajan.

Makanan adalah bagian dari produk kebudayaan yang mencirikan identitas suatu bangsa dan suatu daerah (Yufiza, 2010: 145). Makanan diciptakan dan dikembangkan oleh setiap kelompok manusia atau suku bangsa. Makanan yang ditumbuhkembangkan di lingkungannya masing-masing seperti itu disebut makanan tradisional (Ria Andayani S., 2006: 186).

Istilah tradisional berasal dari kata tradisi yang menurut Heddy Shri Ahimsa Putra (2007: 2) berasal dari bahasa Belanda traditie atau dari bahasa Inggris tradition. Kata tradition memiliki banyak arti yang secara garis besar dapat berarti sebagai suatu tindakan dan sesuatu yang dikenai tindakan.

Sebagai tindakan, tradisi berarti tindakan memberikan dari satu orang ke orang lain secara lisan atau dengan praktik tanpa tulisan. Sedangkan sebagai sesuatu yang dikenai tindakan, tradisi berarti sesuatu yang diwariskan dari generasi ke generasi, suatu adat-istiadat atau metode prosedur yang sudah lama mapan dan diterima umum, yang kekuatannya hampir seperti hukum (Heddy Shri Ahimsa Putra, 2007: 2). Disimpulkan kemudian oleh Heddy bahwa tradisi didefinisikan sebagai sejumlah kepercayaan, pandangan atau 
praktik yang diwariskan dari generasi ke generasi tidak melalui tulisan (biasanya secara lisan atau lewat contoh tindakan), yang diterima oleh suatu masyarakat atau komunitas sehingga menjadi mapan dan mempunyai kekuatan seperti hukum (2007: $3)$.

Kata "tradisi" merupakan kata benda, sedangkan "tradisional" merupakan kata sifat. Istilah 'tradisional' sering dipertentangkan dengan 'modern'. Sehingga, kata 'tradisional' biasanya diartikan sebagai 'kuno', 'tidak modern', dan karenanya sering diasosiasikan dengan 'ketinggalan zaman', 'terbelakang', 'tidak maju', dan karenya 'tidak menarik' (Heddy Shri Ahimsa Putra, 2007: 5). Meskipun diartikan sebagai kuno, menurut Heddy 'tradisional" tidak harus selalu bermakna 'tidak menarik'. Dalam konteks tertentu, justru sesuatu yang masih bersifat tradisional adalah sesuatu yang lebih banyak dicari untuk dikagumi (2007: 5).

Terkait dengan persoalan identitas atau jati diri, Heddy Shri Ahimsa Putra berpendapat bahwa:

"Dalam kehidupan sehari-hari, sebagian unsur kebudayaan dimanfaatkan sebagai sarana untuk menyatakan jati diri. Jati diri atau identitas dapat didefinisikan sebagai "sekumpulan simbol atau tanda...baik fisik, material maupun perilaku...yang membuat seorang individu atau sekumpulan individu terlihat berbeda dengan individu atau kumpulan individu yang lain" (2013: 11).

Selanjutnya, Heddy Shri Ahimsa Putra mengutarakan bahwa:

"Identitas sosial budaya umumnya bersifat achieved, yaitu diperoleh melalui proses sosialisasi atau proses belajar. Identitas sosial budaya biasanya dapat segera terlihat melalui pakaian, logat bahasa, atau perilaku tertentu seperti ketika seseorang berbicara, makan, atau melakukan aktivitas tertentu" (2013: 12).
Dalam konsep kebudayaan Sunda, bahan makanan diambil dari lingkungan alam yang ada di sekitarnya, di tempat yang dihuni masyarakat Sunda. Dengan demikian, corak makanan orang Sunda secara tradisional dipengaruhi oleh corak lingkungan fisik alam Jawa Barat. Adapun proses mengolah dan mewujudkan dari bahan mentah menjadi makanan, serta mengkonsumsikannya dilakukan secara tradisional. Selanjutnya, teknologi tradisional dalam hal mengolah makanan tersebut mewujudkan adanya makanan khas Sunda (Siti Dloyana Kusumah dan H. Ahmad Yunus, 1986: 1).

Namun demikian manakala waktu terus berjalan dan modernisasi akrab dengan kehidupan sehari-hari maka makanan yang tercipta kemudian adalah makanan-makanan yang sifatnya modern. Jenis-jenis makanan yang diproduksi cenderung berorientasi ke Barat dan Timur non-Indonesia (makanan internasional). Jenis makanannya dicirikan dengan nama makanan yang menggunakan istilah asing, bahannya serba buatan pabrikan, serta pembuatannya dengan menggunakan alatalat yang canggih. Sebut saja di antaranya ada ichi bento, zuppa-zuppa, kebab, pizza, burger, dan hotdog. Sebab dari kondisi ini adalah karena Indonesia adalah negara yang sedang berkembang sehingga keberterimaan untuk hal-hal yang sifatnya baru cenderung mudah. Mulai dari gaya hidup, pakaian, teknologi, dan tidak ketinggalan juga adalah makanan (Yufiza, 2010: 145).

Fenomena merebaknya makanan modern pada awalnya memang mampu memarginalkan keberadaan makanan tradisional. Makanan yang sifatnya sederhana, baik itu dilihat dari bahan, peralatan, maupun cara pengolahan dan penyajiannya. Namun demikian seiring berjalannya waktu, secara perlahan-lahan, beberapa makanan tradisional bangkit dari keterpurukkannya. Fenomena ini ditunjukkan dengan menjamurnya penjual makanan tradisional hingga ke kawasan mal, kawasan pusat perbelanjaan. 
Melalui tulisannya yang berjudul "Revitalisasi Makanan Lokal", Yufiza menjelaskan tentang fenomena di atas sebagai berikut:

"Era makanan yang baru (atau sering dikenal dengan makanan cepat saji) agar dikatakan lebih modern sudah mulai redup. Identifikasi orang agar disebut modern tidak lagi muncul ketika mereka makan burger, fried chicken, pizza, dan lain-lain. Meredupnya selera makanan Barat atau orang menyebut sebagai "makanan modern" itu muncul setelah produksi rumah tangga bahkan kaki lima dari produk tersebut bisa dilakukan alias tidak perlu lagi pergi ke restaurant besar atau bahkan ke luar negeri" (2010: 146).

Mengapa fenomena di atas dapat terjadi, kiat-kiat apa yang dilakukan penjual makanan tradisional hingga kehadiran mereka dapat diterima kembali.

Berkenaan dengan pertanyaan tersebut, penelitian ini ingin menguak kiatkiat penjual makanan tradisional dalam upaya menembus pasar. Ruang lingkup penelitian terbagi atas ruang lingkup wilayah dan ruang lingkup materi.

Wilayah penelitian dibatasi di lingkungan mal di kawasan Bandung Timur, tepatnya di kawasan Metro Indah Mal (MIM) atau yang sebelumnya lebih dikenal dengan Metro Trade Center (MTC).

Adapun ruang lingkup materinya tentang penjual makanan tradisional, dalam hal ini seblak. Ada beberapa penjual makanan tradisional yang mengalami nasib serupa penjual seblak, seperti di antaranya penjual gehu 'tahu isi', lumpia basah, dan cilok 'aci dicolok'. Namun demikian dalam penelitian ini, materi dibatasi dengan hanya mengambil sampel penjual seblak. Pertimbangannya adalah belakangan ini seblak menjadi makanan jajanan yang sedang booming. Seblak menjamur dari mulai lingkungan sekolah, perumahan, hingga mal-mal.
Materi yang akan digali dalam penelitian ini adalah: sejarah berdirinya penjualan seblak, asal-usul nama seblak, tujuan menjual seblak, pemilihan waktu dan tempat menjual seblak, perolehan pengetahuan tentang seblak, deskripsi tentang bahan-bahan yang digunakan untuk membuat seblak, peralatan yang digunakan untuk membuat seblak, dan cara pengolahan atau pembuatan seblak.

\section{B. METODE PENELITIAN}

Penelitian yang terkait dengan kebangkitan makanan tradisional ini bersifat deskriptif analisis. Pada taraf deskriptif, peneliti hanya melukiskan keadaan objek atau peristiwanya tanpa mengambil kesimpulan yang berlaku secara umum (Sutrisno Hadi dalam Beni Ahmad Saebani, 2012: 66). Adapun menurut Subino, deskriptif adalah penggambaran sesuatu peristiwa yang sedang terjadi, sedangkan analisis adalah proses mengaitkan antara variabel yang satu dengan lainnya (Ali Gufron, 2012: 513).

Metode untuk penelitian ini adalah metode penelitian kualitatif. Metode penelitian kualitatif adalah metode penelitian yang digunakan untuk meneliti pada kondisi objek yang alamiah (sebagai lawannya adalah eksperimen) bahwa peneliti adalah sebagai instrumen kunci, teknik pengumpulan data dilakukan secara triangulasi (gabungan), analisis data bersifat induktif, dan hasil penelitian kualitatif lebih menekankan makna daripada generalisasi (Beni Ahmad Saebani, 2012: 73).

Mengacu pada apa yang dikemukakan Beni Ahmad Saebani terkait dengan teknik penelitian, penelitian ini dilakukan dengan melalui tujuh tahapan kerja, yakni:

- identifikasi masalah;

- perumusan masalah;

- penelusuran pustaka;

- rancangan penelitian;

- pengumpulan data;

- pengolahan data; 
- Penyimpulan hasil penelitian (2012: 64). Terkait dengan ketujuh tahapan kerja di atas, ada beberapa tahapan yang dijelaskan oleh Beni Ahmad Saebani (2012: 68) sebagai berikut:

- Rancangan penelitian atau desain penelitian, mencakup berbagai informasi penting tentang rencana penelitian. Di dalamnya teruraikan tentang pertanyaan fokus penelitian, yakni kiat-kiat apa yang dilakukan penjual makanan tradisional agar produksinya dapat diterima di era sekarang; tujuan penelitian, yakni kiatkiat penjual makanan tradisional dalam menembus pasar; variabel yang digunakan dalam pelitian, dan berbagai prosedur untuk penentuan sampel, penggalian, dan analisis data.

- Pengumpulan data, merupakan proses pengumpulan berbagai data dan informasi yang dibutuhkan dalam penelitian. Prosesnya mengacu pada prosedur penggalian data yang telah dirumuskan dalam desain penelitian. Berdasarkan jenisnya, ada data primer, yakni data yang diperoleh langsung dari narasumber, dalam hal ini penjual seblak; data sekunder, yakni data yang diperoleh di antaranya dari buku, koran; dan data kualitatif, yakni data berupa pernyataan, bukan angka.

- Pengolahan data, merupakan kegiatan menganalisis data dan informasi yang diperoleh dari proses pengumpulan data.

Melandasi penelitian ini, kerangka

berpikir yang digunakan dalam penelitian sebagai berikut:

Turney (lihat Kroeber dan Kluckhohn, 1952) dalam (Ade MK. dkk., 2013: 7), menyatakan bahwa kebudayaan ialah tindakan dan kesatuan aktivitas sadar manusia yang berfungsi membentuk polapola umum untuk menghasilkan temuantemuan, baik yang material maupun yang nonmaterial.

Selain itu, kebudayaan juga dapat dilihat sebagai produk, alat-alat, bendabenda ataupun ide dan simbol. Dalam konteks ini kebudayaan adalah proses dinamis dan produk yang dihasilkan dari pengolahan diri manusia dan lingkungannya untuk mencapai pemenuhan hidup dan keselarasan sosial di dalam masyarakat (Ade MK. dkk., 2013: 7).

Koentjaraningrat berpendapat bahwa kebudayaan itu mempunyai paling sedikit tiga wujud yakni:

- Wujud kebudayaan sebagai suatu kompleks dari ide-ide, gagasan, nilainilai, norma-norma, peraturan dan sebagainya.

- Wujud kebudayaan sebagai suatu kompleks aktivitas kelakuan berpola dari manusia dalam masyarakat.

- Wujud kebudayaan sebagai benda-benda hasil karya manusia (1990: 5).

Koentjaraningrat juga berpendapat bahwa kebudayaan dapat diperoleh dengan cara belajar (1990: 9).

Selaras dengan konsep di atas, teori informasi Van Peursen melihat kebudayaan sebagai siasat manusia menghadapi hari depan. Van Peursen melihat kebudayaan itu sebagai suatu proses pelajaran, suatu "learning process", yang terus menerus sifatnya. Di dalam proses ini bukan saja kreativitas dan inventivitas merupakan faktor penting, melainkan kedua faktor ini kait-mengait dengan pertimbangan-pertimbangan ethis (1985: 5).

$$
\text { Selanjutnya untuk menjadi }
$$

pemahaman bersama maka beberapa istilah/konsep yang digunakan di dalam penelitian ini diberikan penjelasan seperti berikut:

- Penjual, dalam KBBI (2013: 589) diartikan sebagai orang yang menjual.

- Makanan, dalam KBBI (2013: 861-862) diartikan sebagai segala sesuatu yang dapat dimakan (seperti penganan, laukpauk, kue). Selain itu juga diartikan sebagai segala bahan yang kita makan atau masuk kedalam tubuh yang membentuk atau mengganti jaringan tubuh, memberikan tenaga, atau mengatur semua proses di tubuh. 
- Tradisional dalam KBBI berarti menurut tradisi (2013: 1483).

- Modern, dalam KBBI (2013: 924) diartikan sebagai terbaru, mutakhir. Atau, sikap dan cara berpikir serta cara bertindak sesuai dengan tuntutan zaman.

\section{HASIL DAN BAHASAN}

Metro Indah Mal (MIM) adalah sebuah mal yang terletak di kawasan Bandung Timur. Secara administratif, MIM berada di Kelurahan Sekejati, Kecamatan Buah Batu, Kotamadya Bandung. Sebagaimana layaknya kawasan pusat perbelanjaan, mal ini dipenuhi dengan toko yang menjual aneka produk. Mulai dari produk sandang, kosmetika, alat transportasi, buku, teknologi informasi, sampai dengan produk makanan. Di luar bangunan mal, berderet rumah makan yang menyajikan aneka masakan. Di samping itu, terdapat juga penjual aneka makanan dan minuman yang disatutempatkan pada suatu lahan. Selebihnya, di sudut-sudut mal, berdiri penjual makanan dengan tempat yang permanen maupun nonpermanen. Salah satunya adalah penjual seblak.

Konon, menurut salah seorang penikmatnya, istilah seblak sebagai nama sebuah makanan pernah terdengar di akhir tahun 90-an. Pada saat itu penjualnya ada di lingkungan sekolah. Apa yang disebut seblak pada saat itu terbuat dari bahan kerupuk kemplang, cengek (cabe rawit), bawang bodas (bawang putih), cikur (kencur), dan uyah (garam), dan dengan menggunakan sedikit air. Cara pengolahannya: kerupuk dalam keadaan masih mentah direndam dalam sedikit air. Bahan lainnya yakni cengek, bawang bodas, cikur, dan uyah direndos (digerus/diulek). Selanjutnya bumbu ditumis lalu kedalamnya dicampurkan kerupuk. Adukan bahan tersebut menjadi kenyal dan itulah yang disebut dengan seblak.

Melihat dari jenis bahan yang digunakan dan pengolahannya yang hampir serupa, konon seblak bukan tidak mungkin merupakan pengembangan dari makanan tradsional berbahan kerupuk seperti kerupuk ceos atau kerupuk ngojai. Dua jenis makanan tradisional yang terwariskan dari satu generasi ke generasi. Keserupaannya terlihat pada jenis kerupuk yang digunakan dan jenis bahan untuk bumbunya. Hanya saja pengolahannya sedikit berbeda. Pada kerupuk ceos, kerupuk sudah digoreng terlebih dahulu baru dicelupkan kedalam kuah. Adapun pada kerupuk ngojai, pengolahannya sama dengan kerupuk ceos hanya saja bumbunya ditambahkan dengan oncom.

Kalaulah nama seblak sudah terdengar dari mulai akhir 90-an, namun ternyata nama tersebut tidak familiar, tidak menggema, tidak booming. Beda dulu beda sekarang, nama seblak sekarang booming, khususnya di kalangan anak muda. Penjualnya dapat ditemukan di "setiap jengkal" kita melangkah. Sekarang, seblak dibuat dengan bahan yang lebih bervariasi. Bahan dasar seblak bukan saja menggunakan kerupuk, namun dapat pula menggunakan makaroni. Campurannya di antaranya dapat berupa siomay, mi, baso tahu goreng atau yang dikenal dengan istilah batagor, kerupuk kulit, tulang, dan telur. Itu yang umum dipasarkan. Harga seblak dengan menggunakan bahan-bahan semacam itu berkisar 4.000 sampai dengan 10.000 rupiah.

$\begin{array}{cccc}\text { Di kawasan tertentu seperti di } \\ \text { kawasan } & \text { elite } & \text { Dago misalnya, }\end{array}$ campurannya lebih bervariasi lagi. Campurannya berupa bahan masakan yang berkelas atau harganya cukup mahal untuk sebuah jajanan. Di antaranya sayuran brokoli, daging ayam, daging sapi, atau keju. Harga untuk seblak semacam ini berkisar 10.000 sampai dengan 15.000 rupiah.

Melihat harga seblak yang ditawarkan sekarang, tentu saja sangat jauh berbeda dengan harga seblak yang dulu ditawarkan di lingkungan sekolah atau warung-warung. Harganya bisa lebih 
murah karena terkait dengan penggunaan bahan yang hanya satu macam dan penyajiannya pun sekadarnya.

Perkembangan dari variasi bahan yang digunakan sekarang menjadikan tampilan penyajian seblak juga berbeda. Kalau dulu seblak hanya ditempatkan dalam kantung plastik, sekarang seblak ditempatkan dalam foam. Tempat penjualannya pun menggunakan gerobak dorong atau juga dalam bentuk warung permanen dengan tampilan yang menarik. Misalnya, nama warung dituliskan dalam spanduk dengan pilihan warna dan bentuk huruf yang menarik. Daftar menu dicetak dalam selembar kertas berwarna dan ditempelkan pada etalase. Sebagai upaya menarik minat pembeli, ragam menu seblak ditampilkan dalam bentuk foto yang "dikemas" dalam spanduk berbahan plastik.

Dari segi peralatan untuk pengolahannya, ada keserupaan antara peralatan yang digunakan untuk seblak yang dibuat di tahun-tahun awal kelahirannya dengan seblak versi sekarang. Bedanya, terletak pada kualitas bahan atau kemodernan bentuk alatnya. Misalnya, kalau dulu penjualnya menggunakan kompor pompa berbahan minyak tanah, sekarang menggunakan kompor gas. Kalau dulu bahan seblak hanya ditempatkan dalam kantung plastik sebagaimana penjualnya di pasar membungkus bahan tersebut, sekarang diwadahi dalam toplestoples "cantik". Meskipun demikian, secara prinsip kegunaan alat-alat tersebut, baik yang lama maupun yang baru, sama saja.

Berikut gambaran dari salah satu warung seblak yang ada di MIM. Tersebutlah satu merk/nama dari warung seblak. Pemberian nama tersebut bukan tanpa makna. Nama tersebut merupakan singkatan dari "Mantap Rasanya". Nama ini digunakan dengan harapan dapat mensugesti konsumen untuk memercayai bahwa seblak yang dijualnya memang berasa mantap. Dengan demikian, dengan menggunakan nama tersebut diharapkan konsumen berbondong-bondong datang ke warungnya.

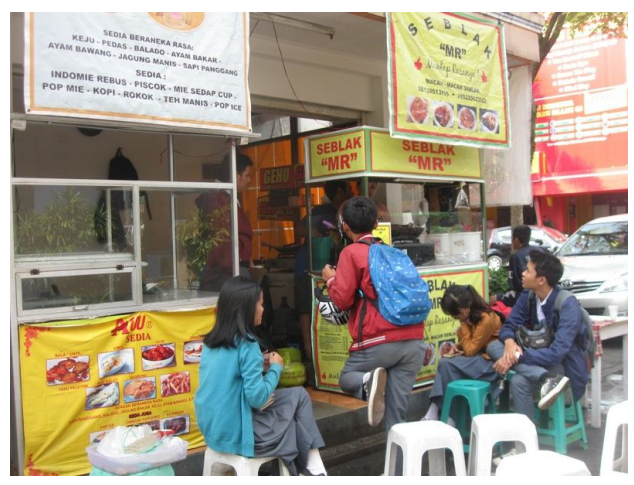

Gambar 1. Warung Seblak Sumber: Ria Intani T.

Mencari arti kata seblak dari Kamus Bahasa Sunda, ada kesamaan arti dengan rasa makanan yang disebut dengan seblak itu sendiri. Dalam Kamus Basa Sunda (R. Satjadibrata, 1954: 362), dijelaskan bahwa seblak, nyeblak: rasa hate dina waktu inget kana balai (ingat pada sesuatu yang kurang enak di hati sehingga hati seperti tersengat). Menurut pemilik warung seblak, kata seblak merupakan singkatan dari segak dan nyegak. Kedua istilah tersebut berasal dari bahasa Sunda yang artinya lebih kurang "menyengat". Segak dan nyegak dalam rasa seblak dicirikan dengan penggunaan cikur. Dengan demikian yang merupakan ciri khas makanan yang disebut dengan seblak adalah rasa cikur-nya.

Warung seblak yang menjadi sampel penelitian berdiri pada tahun 2011 akhir. Sebelumnya dan sampai saat ini, penjualnya menjual gehu rasa pedas atau yang banyak dikenal dengan istilah hot jeletot. Salah satu makanan yang booming sebelum seblak.

Latar belakang penjualan seblak konon semata-mata ingin mengembangkan usaha selain dari yang sudah dilakoninya. Kalau kemudian materi yang dijual pada usaha barunya jatuh pada seblak, hal ini disebabkan pengalamannya di masa lampau. Dulu, ia sering membuat seblak 
bersama ibu-ibu di taman kanak-kanak (TK) di mana anaknya bersekolah. Pada saat itu bahan yang digunakan tidak melulu kerupuk, melainkan bahan yang tersedia di rumah. Seblak yang pernah dibuat di antaranya adalah seblak berbahan kangkung.

Diakuinya, sejak tahun 90-an, semasa duduk di bangku sekolah menengah pertama (SMP), ia sudah mengenal seblak. Pada masa-masa itu, di waktu-waktu senggangnya, ibu dan neneknya sering mengajaknya membuat seblak. "Hayu urang nyeblak, nyandak cikur" (ayo membuat seblak, ambil kencur). Selanjutnya saudaranyalah yang mengajarkannya membuat seblak. Dari sanalah ia mengenal cara membuat seblak. Pada saat itu, seblak yang dibuat menggunakan bahan kerupuk kemplang dengan bahan bumbunya berupa bawang bodas, cikur, cengek, dan uyah. Cara membuatnya dengan merendam kerupuk kedalam sedikit air, merendos semua bumbu lalu menumisnya, baru kerupuk diadukkan ke dalamnya. Kemampuannya dalam membuat seblak tersebut selanjutnya sering dipraktikkan dalam kehidupan sehari-hari sampai ia berumah tangga.

Tujuan utama menjual seblak adalah mengembangkan usaha penjualan makanan. Sedangkan tujuan keduanya adalah mengenalkan makanan tradisional kepada semua kalangan. Baik itu dari kalangan usia kanak-kanak hingga orang tua, laki-laki maupun perempuan. Targetnya ke depan adalah mendirikan cafe dengan menu makanan tradisional.

Tempat yang digunakan untuk berjualan adalah kawasan mal, kawasan pusat perbelanjaan. Di sekitaran tempat berjualan terdapat pusat-pusat kegiatan belajar di luar sekolah, dari mulai tingkat sekolah dasar (SD) hingga sekolah menengah atas (SMA). Kondisi seperti itulah yang dijadikan bahan pertimbangan untuk memilih lokasi berjualan di sana.

Dengan ukuran tempat usaha yang terbatas, pemilik warung menyediakan tempat duduk dengan cara lesehan, dengan menggelarkan selembar karpet kecil. Untuk menjamu pelanggannya yang sering membludak, pemilik warung juga menyediakan beberapa buah kursi yang diletakkan di depan warungnya.

Pada saat datang pembeli, ada bagian yang memasak yang akan membuatkan seblak sesuai pesanan. Sementara pemilik warung menyambangi para pembeli atau ikut duduk bersama pembeli sambil mengobrol. Kedekatan antara pemilik warung dengan pembeli dapat mengecoh orang. Orang akan mengira antarmereka memiliki hubungan kerabat. Kenyataannya mereka adalah penjual dan pembeli. Upaya mendekati pembeli konon dilakukan agar pembeli nyaman berlama-lama di warungnya. Sambil mengobrol, pemilik warung bertanya atau meminta masukan terkait dengan rasa seblak yang dijualnya.

Pengetahuan yang sudah dimiliki tentang seblak di masa SMP menjadi modal utama dalam membuka bisnis seblak. Namun demikian, pengetahuan tersebut dirasa tidak cukup untuk diterapkan pada kondisi sekarang. Ia lalu membuka mata dan telinga lebar-lebar. Ia lakukan survei dengan melihat berbagai bahan yang digunakan pada makananmakanan sekarang. Yakni makanan yang dikonsumsi oleh kalangan muda pada umumnya dan jajanan di lingkungan sekolah.

Dari hasil pengamatannya, ada makaroni yang digunakan sebagai bahan dalam jajanan makaroni basah/kering, batagor (dalam jajanan batagor kering dan kuah), mi dan tulang (dalam mi baso, mi ayam, mi kocok), siomay (dalam paket jajanan baso tahu), telur merupakan bahan makanan/masakan sehari-hari, sosis (dalam paket sosis dan kentang goreng, hotdog), ceker (dalam mi ayam dan mi baso), kwetiau (ada kwetiau kering/kuah, basreng (baso goreng), tahu goreng, dan sebagainya.

Bahan-bahan yang digunakan untuk macam-macam jajanan itulah yang 
kemudian digunakan untuk bahan-bahan seblak versi sekarang. Tidak ketinggalan adalah kerupuk kemplang. Adapun bumbunya pada prinsipnya sama dengan bumbu seblak yang dulu dikenalnya. Ada bawang bodas, cikur, dan uyah yang dijadikan satu sebagai bumbu racikan dan ditambah bumbu penyedap buatan sendiri. Selain itu ada gula putih dan sambal cengek. Sambal cengek dibuat dari cengek yang direbus lalu diblender.

Bukan tidak mungkin bahan yang digunakan di warungnya ada kesamaan dengan penjual seblak lainnya. Entah siapa meniru siapa. Namun itulah sifat folklore yang menyebar dan anonim. Kalaupun terjadi ada kesamaan bahan, namun belum tentu sama dalam segi kesehatan makanannya. Pemilik warung berpikir panjang bahwa pembeli itu harus kembali lagi. Oleh karenanya bukan saja dari segi rasa yang enak yang dipikirkan, akan tetapi seblak yang dijualnya tidak mendatangkan penyakit. Seperti yang disampaikan Oto, bahwa bukan saja kuantitas yang dipentingkan, melainkan juga mutu dari makanan itu sendiri. Pemikirannya jauh sampai pada masalah kesehatan dapat dicontohkan sebagai berikut.

Pemilik warung melihat bahwa beberapa bahan makanan ada yang mengandung bahan pengawet, misalnya pada kerupuk, mi, dan makaroni tertentu. Bahan pengawet tersebut konon tidak baik untuk kesehatan dan bahkan untuk orangorang tertentu dapat dengan cepat menimbulkan reaksi, seperti perut menjadi tidak nyaman. Untuk itulah, sebelum ketiga jenis bahan tersebut digunakan, terlebih dahulu direndam dalam air panas untuk membuang zat pengawetnya. Kemudian ada bumbu penyedap yang siap pakai yang apabila terlalu sering dikonsumsi menimbulkan gangguan di kepala, seperti pusing. Untuk itulah, untuk penyedap rasa, ia membuatnya sendiri. Berdasarkan pengalaman dan pengetahuan dari orang lain maka bahan dan cara pembuatan seblak dilakukan secara aman.

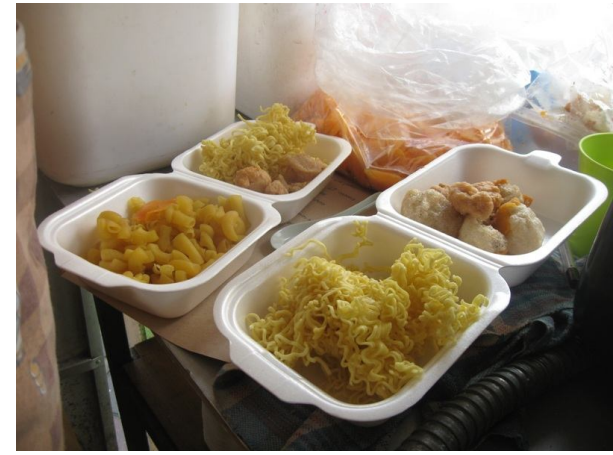

Gambar 2. Bahan Seblak Sumber: Ria Intani T.

Dari macam-macam bahan yang digunakan, terciptalah aneka menu seblak seperti berikut:

\section{MENU SEBLAK}

\section{Seblak Tanpa Telur}

Kerupuk ...................Rp 4000

Makaroni .................. Rp 4000

Mi ........................ Rp 4000

Kwetiau .................... Rp 4000

Kerupuk + Basreng ........ Rp 5000

Kerupuk + Sosis ........... Rp 5000

Kerupuk + Makaroni + Mi Rp 5000

Kerupuk + Makaroni + Kwetiau

Rp 5000

Kerupuk + Siomay........... Rp 6000

Kerupuk + Tahu ............. Rp 6000

Kerupuk + Ceker ..............Rp 6000

Kerupuk + Tulang ......... Rp 6000

\section{Seblak Telur}

Kerupuk + Telur ........... Rp 5000

Makaroni + Telur ........... Rp 5000

$\mathrm{Mi}+$ Telur ................ Rp 5000

Kwetiau + Telur ............ Rp 5000

Kerupuk+Makaroni+Telur... Rp 5000

Kerupuk + Kwetiau + Telur..Rp 5000

Kerupuk + Mi + Telur ..... Rp 5000

Kerupuk + Sosis + Telur .... Rp 5000

Kerupuk + Basreng + Telur Rp 5000

Kerupuk + Siomay + Telur Rp 6000

Kerupuk + Tahu + Telur ... Rp 6000 
Seblak Spesial (4 Item)

Kerupuk + Makaroni + Sosis + Telur .......... Rp. 7000

Kerupuk + Makaroni + Basreng + Telur ... Rp 7000

Kerupuk + Makaroni + Mi + Telur

Rp 7000

Kerupuk + Makaroni + Kwetiau + Telur Rp 7000

\section{Seblak Spesial (6 Item) \\ Rp 8.000 - Rp 10.000}

Kerupuk + Makaroni + Mi + Sosis + Baso

+ Telur

$\mathrm{Mi}+$ Kwetiau + Makaroni + Siomay +

Tahu + Telur

Tulang + Ceker + Siomay + Tahu $+\mathrm{Mi}+$

Telur

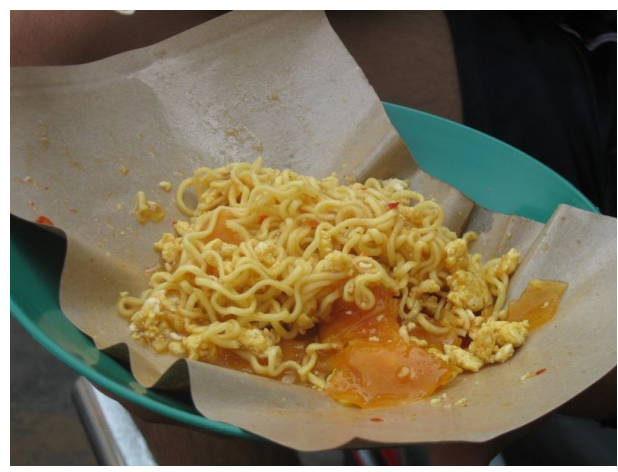

Gambar 3. Seblak

Sumber: Ria Intani $\mathrm{T}$.

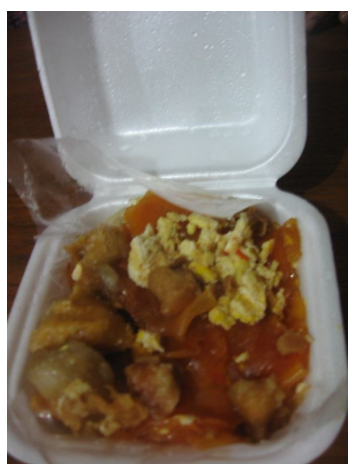

Gambar 4. Seblak

Sumber: Ria Intani T.

Apa pun menu seblak yang dipesan oleh pembeli, cara pembuatan atau pengolahannya sama. Berikut satu contoh cara membuat seblak dengan menu

kerupuk + mi + telur:

- menumis bumbu racikan dengan sedikit minyak goreng;

- telur dimasukkan kedalam tumisan bumbu sambil terus diaduk agar telur tidak menggumpal;

- air matang dimasukkan kedalam tumisan lalu didiamkan sampai mendidih;

- kerupuk dan mi mentah dengan takaran per satu porsi dimasukkan kedalam tumisan yang sudah berkuah;

- adonan diaduk sebentar sampai kerupuk dan mi matang atau kenyal;

- adonan diberi sedikit gula putih dan sambal (bagi yang menginginkan rasa pedas).

Manakala seblak sudah matang, kepada pembeli selalu disarankan untuk mencicipinya terlebih dahulu, sebelum dituangkan kedalam piring atau foam. Maksudnya, agar rasa seblak tersebut sesuai dengan yang diinginkan pembeli. Motto warungnya adalah seblak selera konsumen, bukan selera penjual.

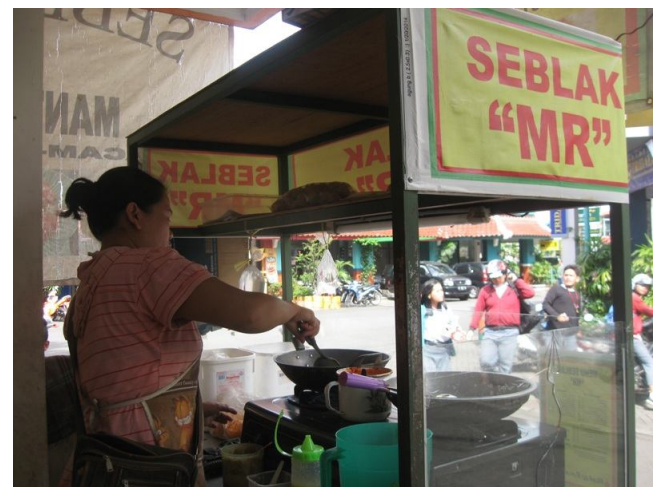

Gambar 5. Membuat Seblak Sumber: Ria Intani T. 


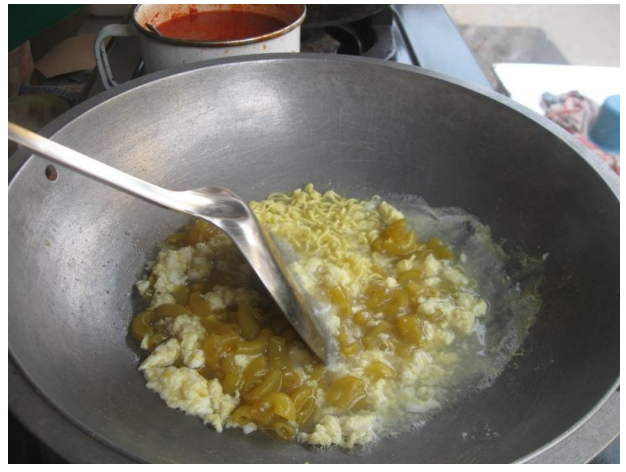

Gambar 6. Membuat Seblak Sumber: Ria Intani T.

Peralatan untuk mengolah seblak di antaranya berupa: kompor gas dan katel lengkap dengan susuk-nya, teko plastik sebagai tempat air, cangkir seng untuk tempat sambal, botol plastik untuk tempat bumbu racikan, dan toples-toples plastik untuk tempat bahan-bahan seblak. Alat penyajiannya berupa foam untuk seblak yang dibawa pulang, lengkap dengan sinduk bebek plastik. Adapun seblak untuk disantap di tempat, wadahnya berupa piring plastik atau piring rotan yang dialasi kertas nasi.

Warung ini dalam satu hari menjual 200-250 porsi seblak. Porsi sebanyak itu selain habis oleh pembeli yang hanya sesekali datang, juga oleh para pelanggan. Ibu-ibu biasanya akan membeli seblak untuk disantap di rumah. Sedangkan kalangan muda banyak yang menyantap di tempat. Saat ini, selain di MIM, dua cabang lainnya yakni di daerah Bodogol (Ciwastra) dan Jalaprang (Suci).

\section{PENUTUP}

Tulisan ini bukanlah dimaksudkan untuk sekadar mengenalkan makanan yang disebut dengan seblak. Apa yang dipaparkan di atas lebih pada tujuan untuk menggambarkan kebudayaan sebagai suatu produk dan ide/gagasan, suatu aktivitas, sekaligus sebagai suatu proses belajar.

Upaya yang dilakukan pemilik usaha untuk menjadikan seblak dapat diterima kehadirannya di tengah-tengah makanan modern menunjukkan bahwa kebudayaan sebagai suatu aktivitas (lihat Ade MK. dkk., hlm. 3 dan Koentjaraningrat hlm. 4). Di sini ada upaya menjadikan seblak dari makanan tradisional menjadi makanan modern. Aktivitas yang dilakukan adalah dengan terus menghasilkan temuan-temuan dengan cara mencari, mencoba, dan menggunakan aneka bahan untuk membuat seblak. Hasil temuannya menjadikan seblak yang pada awalnya hanya berbahan kerupuk ke seblak dengan bahan yang lebih bervariasi (lihat aneka menu seblak).

Penggunaan bahan-bahan yang sifatnya familiar di era sekarang ini, mampu mengubah seblak dari jajanan "kampung" menjadi jajanan bergengsi, dari jajanan "murahan" menjadi jajanan "mahal". Apabila dilihat dari kaca mata seorang Oto, fenomena ini menunjukkan kalau seblak yang pada awalnya hanya memiliki nilai sosial "rendah" kini dapat dianggap memiliki nilai sosial yang tinggi. Hal ini dibuktikan dengan masuknya seblak ke mal sebagai kawasan pusat perbelanjaan. Kawasan pusat perbelanjaan selama ini menjadi tempat atau image dari makanan yang sifatnya internasional (Yufiza, 2010: 146).

Proses pencarian atau temuan baru (lihat aneka bahan) yang kemudian menjadikan seblak jadul (jaman dulu) menjadi seblak "modern", menunjukkan bahwa kebudayaan merupakan suatu ide/gagasan. Di samping itu, kebudayaan (baca: makanan) sebagai produk atau benda hasil karya manusia sifatnya dinamis (lihat Ade MK. dkk., 2013: 7 dan Koentjaraningrat, 1990: 5).

Berdirinya warung seblak sebagai kelanjutan atau pengembangan dari usaha makanan tradisional yang sebelumnya, menunjukkan bahwa kebudayaan sebagai proses belajar. Penambahan atau pengembangan usaha merupakan hasil dari mempelajari pasar sekaligus merupakan sikap tanggap terhadap keadaan pasar. Pendirian warung seblak 
didorong oleh peminat makanan tradisional yang terus meningkat.

Proses belajar tak pernah berhenti sampai di sana. Setelah warung seblak berdiri, proses pembelajaran dilakukan dengan mau bertanya dan menerima masukan dari orang lain. Belajar dari pengalaman, pemilik usaha harus selalu siap untuk mengubah atau mengembangkan usahanya. Kreativitas pengusaha makanan menjadi faktor penting untuk menciptakan produk baru dari makanan lama. Seperti dikatakan Van Peursen yang melihat kebudayaan sebagai siasat manusia menghadapi hari depan. Kebudayaan itu sebagai suatu proses pelajaran, suatu "learning process", yang terus menerus sifatnya.

Suatu kebanggaan tersendiri, di keramaian ibu kota provinsi yang sekaligus penyangga ibu kota negara, makanan tradisional masih dapat hadir dan di terima di tengah-tengah beragam makanan modern. Fenomena ini tentu saja perlu diapresiasi oleh pemerintah. Oleh karena para pegiat makanan itulah maka makanan tradisional dapat lestari.

Selanjutnya, sebagaimana tugas dari instansi terkait, kemunculan para pegiat makanan tradisional itu perlu ditindaklanjuti dengan kegiatan pelestarian. Istilah pelestarian mengandung tiga hal, yakni: perlindungan, pemanfaatan, dan pengembangan.

Perlindungan, pemerintah wajib melindungi keberadaan makanan tradisional. Sesuai kapasitasnya, pemerintah dapat menguatkan keberadaan pegiat makanan tradisional dengan berbagai cara. Di antaranya: menjadikan makanan tradisional sebagai sajian wajib para tamu, khususnya di lingkungan pemerintahan. Baik itu tamu dari dalam kota, luar kota, dan apalagi mancanegara; membantu mempromosikan makanan tradisional di berbagai even; ruang-ruang publik, seperti gedung bioskop misalnya, diwajibkan "menyajikan" makanan tradisional melalui tayangan iklan yang menarik. Dengan kata lain, ruang publik harus dapat digunakan sebagai sarana sosialisasi; membangun museum makanan tradisional. Materinya berupa foto-foto tiap jenis makanan, bahan dan peralatan untuk membuatnya, serta cara pembuatannya. Lebih menarik lagi apabila tiap jenis makanan bukan saja tergambarkan dalam bentuk foto, melainkan dapat dibuatkan replikanya. Selain itu, kalau di Kota Bandung sudah berdiri aneka taman seperti Taman Musik, Taman Fotografi, dan sebagainya, alangkah baiknya ditambahkan pula Taman Jajanan Sunda. Di taman ini, para pegiat makanan tradisional mendapatkan ruang dan kesempatan untuk mensosialisasikan makanan tradisional (Sunda) kepada masyarakat luas. Lebih jauh lagi, pemerintah dapat membuatkan hak paten untuk tiap-tiap jenis makanan. $\mathrm{Hal}$ ini perlu dilakukan untuk mengantisipasi agar kepemilikan makanan tradisional bangsa Indonesia tidak diakui oleh bangsa lain.

Pemanfaatan, pemerintah wajib memanfaatkan makanan tradisional sebagai materi sajian para tamu di berbagai even. Dengan cara ini, para pegiat makanan akan terus eksis dan makanan tradisional tidak pernah terlupakan, khususnya oleh para pendukung budayanya sendiri.

Pengembangan, pemerintah wajib membantu mengembangkan makanan tradisional. Caranya dengan menjadikan makanan tradisional menjadi makanan yang dapat diterima oleh semua kalangan di semua ruang dan waktu. Pemerintah memprogramkan berbagai pelatihan. Di antaranya berupa: pelatihan managerial, pengelolaan keuangan, pemasaran, teknikteknik pengemasan, pengetahuan tentang kesehatan makanan, tentang motivasi, dan sebagainya. Berbekal dari berbagai pelatihan, diharapkan dapat memperbesar usaha para pegiat makanan.

Selanjutnya, melihat kondisi pasar makanan tradisional yang terus membaik, ada baiknya pemerintah (baca: instansi terkait) menggerakkan pegiat makanan tradisional untuk merevitalisasi makanan- 
makanan jadul menjadi makanan "modern". Tujuannya tidak lain agar beragam makanan tradisional yang menjadi kekayaan suku bangsa khususnya dan bangsa Indonesia pada umumnya, tidak hilang tertelan zaman. Istilah revitalisasi secara harfiah dapat diartikan sebagai pengaktifan atau pemfungsian kembali sesuatu yang tidak atau kurang berdaya (Singgih Tri Sulistiyono, 2013: 20).

Dari paparan di atas, ada beberapa nilai yang dapat diambil, seperti :

- Nilai pendidikan; dilihat dari segi pendidikan, fenomena kebangkitan makanan tradisional dapat membuka mata generasi muda bahwasanya budaya lokal tidak kalah dengan budaya nonlokal (nasional) dan bahkan budaya internasional. Fenomena ini mengajarkan pada generasi muda untuk mencintai budaya suku bangsa dan bangsanya sendiri. Selain itu, hanya dengan kemauan untuk belajar dan belajarlah yang dapat menghantarkan seseorang untuk sukses.

- Nilai kreativitas; kreativitas terbukti mampu merevitalisasi dari yang "tidak berguna" menjadi berguna, dari makanan jadul menjadi makanan "modern" yang dapat diterima semua kalangan. Pada akhirnya, dengan kreativitas pula mampu meningkatkan nilai ekonomi.

- Nilai optimisme; setiap upaya perlu didasari dengan keyakinan diri oleh karena keyakinan diri mampu memotivasi seseorang dalam mencapai dan mempercepat pencapaian tujuan.

- Nilai visioner; orang harus selalu melihat ke depan dengan belajar dari pengalaman.

\section{DAFTAR SUMBER}

\section{Jurnal, Makalah, Laporan Penelitian}

Gufron, Ali. "Sistem Pengetahuan Tradisional Masyarakat Petani Desa Cijagang
Kecamatan Cikalong Kulon Kabupaten Cianjur" dalam Jurnal Patanjala Vol. 4 No. 3 September 2012 hlm. 513.

Kartawinata, Ade Makmur., Ria Andayani S., Ali Gufron, Nina Merlina, Yuzar Purnama, Iwan Roswandi, T. Dibyo Harsono, Hary Ganjar Budiman. Kajian Nilai Budaya Lokal Masyarakat Jatigede, Laporan Penelitian. BPNB Bandung 2013.

Putra, Heddy Shri Ahimsa. "Peran dan Fungsi Nilai Budaya dalam Kehidupan Manusia", Makalah dalam Diklat Peneliti Tingkat Lanjutan, Jakarta, 1522 Januari 2007.

Putra, Heddy Shri Ahimsa. "Budaya Bangsa, Jati Diri dan Integrasi Nasional Sebuah Teori” dalam Jurnal Sejarah dan Nilai Budaya Nusantara Edisi Perdana Tahun I 2013 hlm. 11.

Sulistiyono, Singgih Tri. "Revitalisasi Nasionalisme melalui Penguatan Ketahanan Budaya Bangsa" dalam Jurnal Sejarah dan Nilai Budaya Nusantara Edisi Perdana Tahun I 2013 hlm. 20.

Yufiza. "Revitalisasi Makanan Lokal" dalam Jurnal Jnana Budaya Edisi 15/VIII/2010 hlm 146.

\section{Buku}

Andayani S., Ria. 2006.

"Makanan Tradisional Masyarakat Betawi", dalam Ani Rostiyati dan Toto Sucipto, Budaya Masyarakat Betawi, Bandung: Balai Kajian Sejarah dan Nilai Tradisional, hlm. 120 dan 186.

Kusumah, Siti Dloyana dan H. Ahmad Yunus (ed). 1986.

Makanan: Wujud Variasi dan Fungsi serta Cara Penyajiannya pada Orang Sunda Daerah Jawa Barat. Depdikbud: Proyek IDKD.

Koentjaraningrat. 1990. 
Kebudayaan Mentalitas dan

Pembangunan. Jakarta: PT Gramedia Pustaka Utama.

Merlina, Nina. 2006.

"Makanan Tradisional Masyarakat Banten", dalam Adeng dan Sindu Galba. Sistem Teknologi Tradisional, Bandung: Balai Kajian Sejarah dan Nilai Tradisional, hlm. 95-96.

Satjadibrata, R. 1954.

Kamus Basa Sunda. Djakarta: Perpustakaan Perguruan Kementerian P. P Dan K.

Saebani, Beni Ahmad. 2012.

Pengantar Antropologi. Bandung: CV Pustaka Setia.

Tim Penyusun Kamus Besar Bahasa Indonesia. 2013.

Kamus Besar Bahasa Indonesia Edisi Keempat. Pusat Bahasa. Departemen Pendidikan Nasional. Jakarta: PT Gramedia Pustaka Utama.

Van Peursen, C. A. 1985.

Strategi Kebudayaan. Yogyakarta: Kanisius. 